\title{
Predator distribution and habitat patch area determine predation rates on Age-0 juvenile cod Gadus spp.
}

\author{
B. J. Laurel ${ }^{1, *}$, R. S. Gregory ${ }^{2}$, J. A. Brown ${ }^{1}$ \\ ${ }^{1}$ Ocean Sciences Centre, Memorial University of Newfoundland, St. John's, Newfoundland A1C 5S7, Canada \\ ${ }^{2}$ Department of Fisheries and Oceans, Science Branch, PO Box 5667, St. John's, Newfoundland A1C 5X1, Canada
}

\begin{abstract}
Eelgrass Zostera marina provides refuge to numerous fish species but is vulnerable to fragmentation through natural and anthropogenic disturbance. In Bonavista Bay, Newfoundland, eelgrass patch size was altered to measure changes in predation risk in Age-0 juvenile cod, Gadus morhua. Artificial eelgrass mats of 5 sizes $\left(0.32,1.1,5.5,11\right.$ and $\left.22 \mathrm{~m}^{2}\right)$ were deployed in duplicate at each of 2 sites in Newman Sound in Terra Nova National Park during summer/autumn in 1999 and 2000. Predator distribution was determined using a combination of weekly underwater transect surveys and biweekly seining. Relative predation rates were measured by tethering Age- 0 cod at the center of each patch and recording the incidence of predation $(n=1116$ tether sets). Predation rates were negatively correlated with patch size during both years, suggesting that larger patches reduce predator foraging ability. However, high predator densities in the largest eelgrass patch resulted in higher than expected rates of predation. Therefore, habitat dimension affected predation risk in juvenile cod via 2 opposing mechanisms. Our results stress the importance of considering both habitat areal extent and predator distribution when estimating the effects of habitat fragmentation on predation rates.
\end{abstract}

KEY WORDS: Predator-prey interactions $\cdot$ Edge effects $\cdot$ Eelgrass $\cdot$ Juvenile cod $\cdot$ Predator distribution · Habitat fragmentation

\section{INTRODUCTION}

Seagrass beds provide shelter to a variety of juvenile fish species in coastal environments across a range of latitudes (e.g. Orth et al. 1984, Sogard \& Able 1991, Laurel et al. unpubl. data). Fragmentation of these beds occurs both naturally (e.g. seasonal die-off, waveaction, ice scour) and anthropogenically (e.g. inshore boating, nitrogen loading; Fonseca 1992). Consequently, seagrass habitats are often patchy, ranging from single plants to expansive meadows greater than $1000 \mathrm{~m}^{2}$ (Robbins \& Bell 1994).

Juvenile fish often use complex habitats to offset the threat of predation (e.g. Werner et al. 1983a,b, Mittelbach 1986). However, increased habitat fragmentation of seagrass beds may have negative consequences for young refuge-seeking fish. Predation risk is highest during the early life stages of marine fish (Sogard
1997) and complex habitat reduces risk by interfering with the visual and swimming capabilities of piscivores (Gotceitas \& Colgan 1989). However, predators may compensate for reduced foraging efficiency by feeding along the edges of complex habitat (Peterson et al. 2001). Therefore, predation risk may be higher in fragmented habitats with increased edge to area ratios (e.g. small patches). Small, fragmented patches may also be riskier because their interior is closer to the more dangerous edges. These explanations have been invoked to explain increasing predation risk with smaller habitat patches in both terrestrial (Levenson 1981) and marine systems (Irlandi 1997).

There has been considerable variation in the results of edge effects/patch size on predation rate (reviewed by Paton 1994). Equivocal results have prompted more studies to examine the local abundance of predators and prey (Donovan et al. 1997). For example, rates of 
piscivory in eelgrass habitats can be equal to or higher than unstructured sand habitats, despite the reduced foraging ability of predators in complex habitats (Linehan et al. 2001, Gregory et al. unpubl. data). Differences in predation rate were attributed to higher numbers of predators in eelgrass habitats compared to unvegetated sand. Therefore, the interaction of habitat characteristics (e.g. complexity, perimeter to edge ratios) on predator distribution must be considered when quantifying predation risk across habitats.

Atlantic cod Gadus morhua is a commercially important demersal species that occupies nearshore areas in the northwest Atlantic Ocean during the first year of life (Taggart et al. 1994). As juveniles, cod associate with complex habitats, such as boulders/large rock (Gregory \& Anderson 1997), cobble (Tupper \& Boutlier 1995), macroalgae (Keats 1990) and eelgrass (Gotceitas et al. 1997), for protection from predators, such as larger conspecifics and other piscivorous fish as well as seabirds. Laboratory experiments have shown that complex habitats can reduce predation risk for juvenile cod when exposed to actively foraging predators (Gotceitas \& Brown 1993, Gotceitas et al. 1995, Lindholm et al. 1999). However, recent studies have shown that predators of juvenile cod also prefer complex habitat (Linehan et al. 2001, R. Gregory unpubl. data) and may

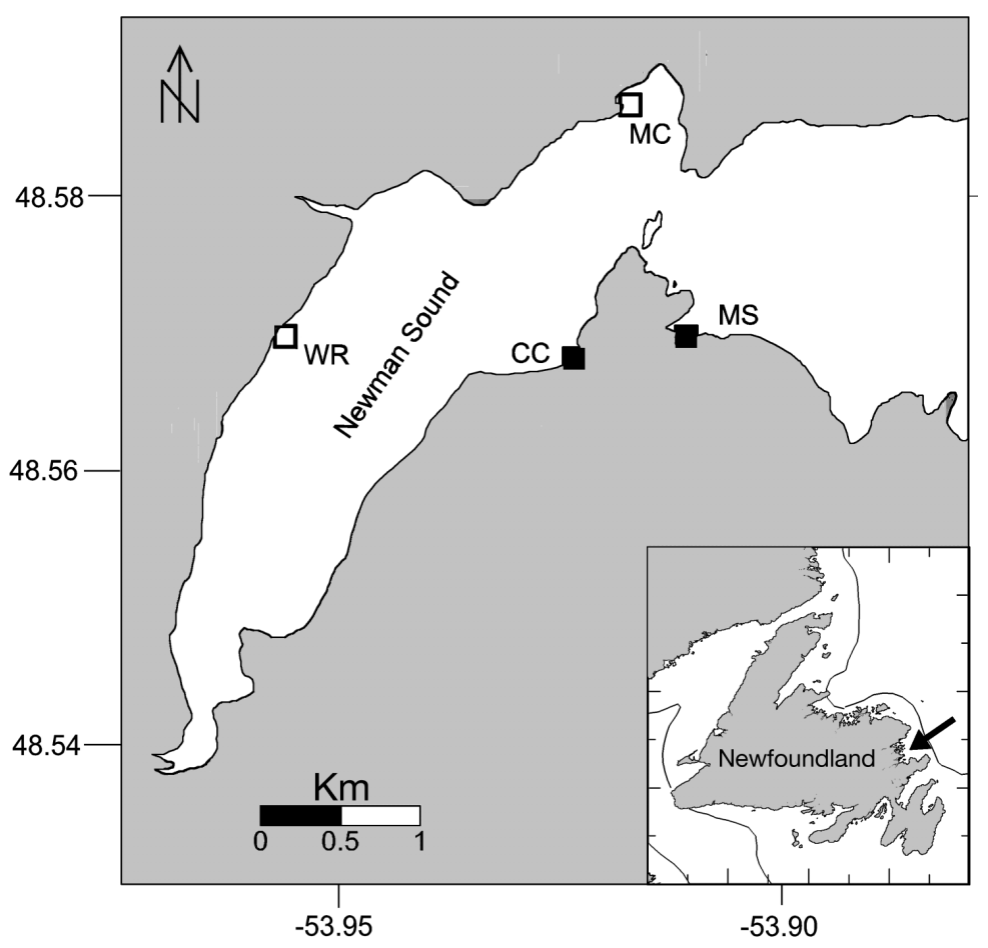

Fig. 1. Locations of eelgrass patches in Newman Sound, Bonavista Bay, Newfoundland. Artificial eelgrass locations: Canning's Cove (CC) and Mt. Stamford (MS) (ם); natural eelgrass locations: White Rock (WR) and Mistaken Cove (MC) ( $\square$ ) elevate risk in these habitats. Therefore, the role of habitat characteristics on predation risk in juvenile cod remains unclear.

No studies have been conducted in marine systems examining the effects of habitat patch size and local predator abundance on predation rates. Earlier investigations considering both habitat characteristics and predator distribution have been restricted to a few large-scale avian studies (reviewed by Donovan et al. 1997). In this study, we measured the distribution of piscivorous fish and the rate of predation on tethered Age-0 cod in varying sized seagrass patches. We addressed the following questions: (1) Does risk change with increasing eelgrass patch size? and (2) How do habitat patch area and localized predator distribution interact to affect risk in Age-0 juvenile $\operatorname{cod}$ ?

\section{MATERIALS AND METHODS}

Study area. Newman Sound is located within Bonavista Bay off the northeast coast of Newfoundland in the vicinity of Terra Nova National Park (TNNP; Fig. 1). The nearshore habitat (0 to $15 \mathrm{~m}$ depth) varies between eelgrass Zostera marina, macroalgae (e.g. Laminaria digitata, Chondrus crispus) and fine- to coarsegrain mineral habitats. We conducted experiments in 2 coves within the sound: Canning's Cove (CC) and Mt. Stamford Cove (MS). These sites were chosen mainly because they lack any complex habitats such as boulders and/or eelgrass, were of similar depth in the experimental area (1.5 to $2.5 \mathrm{~m}$ ) and were also conducive to hauling a net along the bottom.

Artificial eelgrass. Artificial eelgrass was manufactured using galvanized screen $(2.5 \mathrm{~cm}$ pore size) and green curling ribbon $(0.8 \mathrm{~cm}$ width). Ribbon was tied onto the screen to create blades $75 \mathrm{~cm}$ long at a density of 400 blades $\mathrm{m}^{-2}$, falling within the range of length and density for naturally occurring eelgrass (Orth et al. 1984). Eelgrass mats were cut into varying length strips to form approximately square patches $0.32,1.5,5.5,11$ and $22 \mathrm{~m}^{2}$ in size. SCUBA divers secured replicates of each of these patch sizes to the bottom at each site using reinforcing bar (i.e. re-bar) spikes (Fig. 2). Eelgrass mats were attached flush against the substrate by staggering spikes at $0.5 \mathrm{~m}$ distances along their entirety. This reduced possible damage from wave action and also minimized the effect of added complexity from the wire mesh frames. Spacing between patches edges was kept constant 
at $3 \mathrm{~m}$ for both sites. Patches in 1999 were deployed in July, approximately 1 mo prior to Age-0 juvenile cod settlement in coastal Newfoundland (Methven \& Bajdik 1994, Grant \& Brown 1998a). Artificial blades of eelgrass became fouled with epiphytes throughout the season similar to natural eelgrass. In November 1999, patches were removed, cleaned of epiphytes and stored dry before being redeployed again in July 2000. No significant degradation in the artificial eelgrass (i.e. mesh rust, blade loss, etc.) was observed in either of the 2 years of the experiment.

Predation rates. Predation within patches was determined using a tethering technique with Age-0 cod collected by seine from nearby sites. We used 2 species of cod (58\% Atlantic cod Gadus morhua and $42 \%$ Greenland cod G. ogac) for tethering. These 2 species co-occur in the nearshore (Methven et al. 2001) at similar sizes within the first year of life. Susceptibility to predation on tether lines is similar for these 2 species (B. Laurel \& R. Gregory unpubl. data).

The tethering apparatus consisted of 2 sections, a $2 \mathrm{~m} 11.2 \mathrm{~kg}$ test vertical float line and a $0.5 \mathrm{~m} 0.9 \mathrm{~kg}$ test horizontal leader line. The float line was kept vertical in the water column using a $564 \mathrm{~g}$ anchor and a cork float $1 \mathrm{~m}$ from the bottom. A white float at the surface marked the location of the tether line and facilitated retrieval. The horizontal leader line was attached to a \#7 barrel swivel on the vertical float line $75 \mathrm{~cm}$ from the bottom substrate. Age- 0 cod were tethered to the leader line via a \#16 hook inserted through the caudal peduncle. The leader line allowed cod prey a $0.5 \mathrm{~m}$ radius of movement and access to the eelgrass. A full description of the tethering apparatus and technique is described in Linehan et al. (2001).

Each tether line was deployed from a small aluminum boat $(4.2 \mathrm{~m})$ at midday, left undisturbed for a period of $15 \mathrm{~min}$ and finally retrieved to determine the incidence of predation. Water clarity was adequate to insure that tethered fish were not lost while being lowered to the bottom. Predation was classified as a 'hook loss', 'fish loss', 'caught predator' or 'predator attack' upon retrieval of the tether line. The absence of predation was recorded if a tethered fish was retrieved alive without any sign of predation, e.g. punctured skin, etc. All predators captured on tether lines were identified, measured to the nearest $0.5 \mathrm{~cm}$ standard length (SL) and released.

Our experimental design consisted of setting tethers at the center of each patch $\left(0.32,1.1,5.5,11\right.$ and $\left.22 \mathrm{~m}^{2}\right)$ and on 6 neighboring areas of unvegetated sand about $3 \mathrm{~m}$ from the nearest patch edges. Tethering in patch and unvegetated areas was repeated 6 times during 3 tethering sessions in each year for a total of 1152 tether sets: [6 unvegetated areas + $(5$ artificial eelgrass patches $\times 2$ patch replicates) $] \times 6$ rounds $\times$

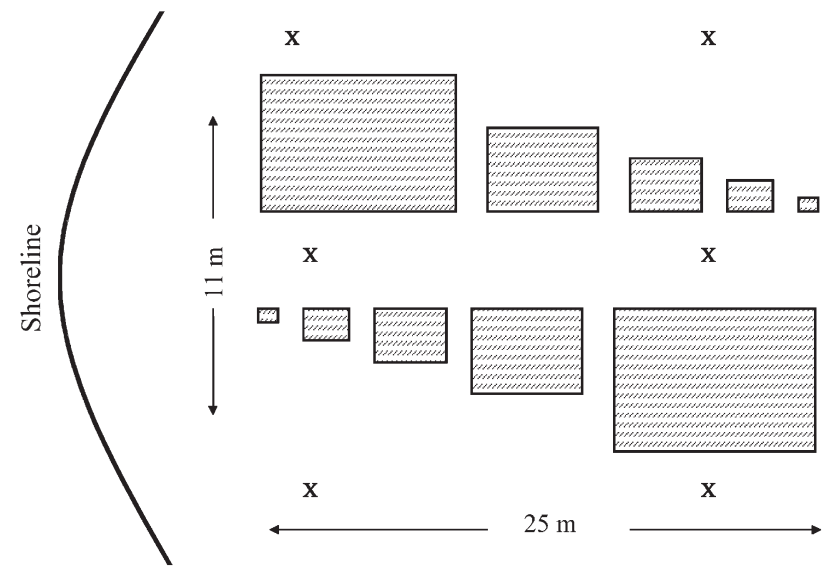

Fig. 2. Experimental layout of artificial eelgrass patches relative to shore at Canning's Cove and Mt. Stamford. Tethers are set at the center of each patch and 6 locations outside of patches (indicated by X)

2 sites $\times 3$ sessions $\times 2$ yr. Tethering sessions were conducted at ca. 2 wk intervals beginning early September of both years and corresponded with concurrent surveys of predator abundance. Tethered prey throughout the time period of the experiment ranged in size from 65 to $106 \mathrm{~mm}$ SL. The range in size represents growth in the available Gadus prey from early September to mid-October of each year. However, variation in prey size was substantively less within individual tethering sessions, i.e. maximum $\pm 11 \mathrm{~mm}$ SL.

Predator distribution. Predator abundance was estimated at 2 wk intervals using a $25 \mathrm{~m}$ Danish bag seine (19 $\mathrm{mm}$ mesh) deployed $55 \mathrm{~m}$ offshore from a boat and hauled to shore by 2 individuals standing $16 \mathrm{~m}$ apart. The seine sampled $880 \mathrm{~m}^{2}$ of bottom habitat up to $2 \mathrm{~m}$ in the water column (for a description see Methven \& Schneider 1998). Captured fish were transferred to holding containers with seawater. Piscivorous fish captured included Greenland cod, Atlantic cod, cunner Tautogolabrus adspersus, sculpin Myoxocephalus spp. and white hake Urophycis tenuis. Potential predators were identified and measured $( \pm 5 \mathrm{~mm}$ SL) and released the same day to their respective sites.

Small-scale, localized predator distribution was measured via snorkeling. Snorkeling surveys were always conducted 3 to $4 \mathrm{~d}$ before or after seining activity to minimize the effects of net disturbance. Snorkelers swam directly over patches, recording the abundance and type of fish predators within $0.5 \mathrm{~m}$ of each patch. Large patches (11 and $22 \mathrm{~m}^{2}$ ) exceeded the viewing capacity of a single snorkeler, so these patches were assessed by 2 snorkelers swimming in parallel. Snorkelers swam with delineated poles (2.82 m each) to minimize overlap of survey areas of the large patches. Water clarity throughout the survey was suffi- 


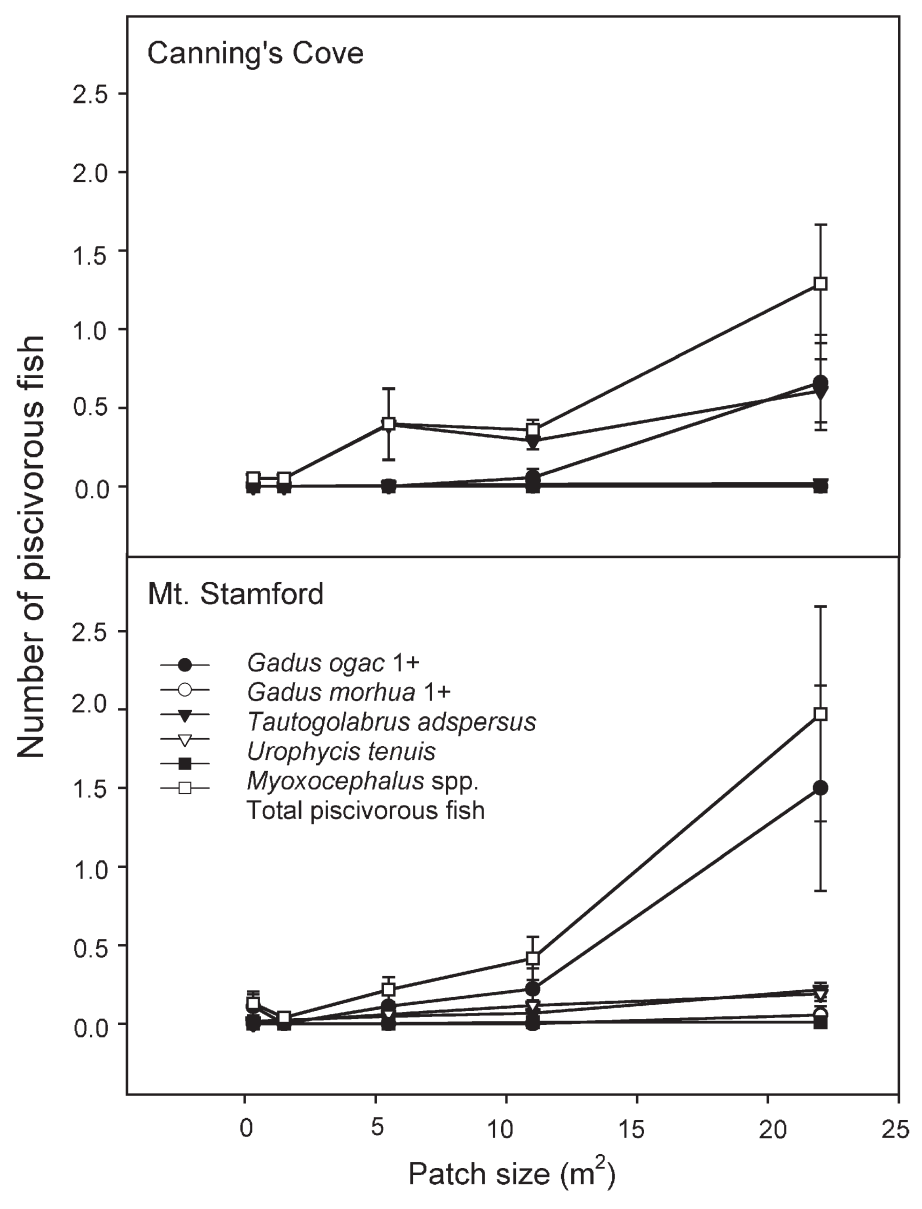

Fig. 3. Mean abundance of predators (Gadus ogac, G. morhua, Tautogolabrus adspersus, Myoxocephalus spp. and Urophycis tenuis) censused via snorkeling at Canning's Cove and Mt. Stamford on various sized patches of simulated eelgrass. Each point represents a mean of 9 snorkel surveys of 2 replicate patches $\pm 1 \mathrm{SE}$

ciently greater (i.e. 5 to $6 \mathrm{~m}$ ) than the maximum area censused by a single snorkeler, i.e. $2.82 \mathrm{~m}$. Experimental sites were visually censused in this fashion between August 10 and October 12, 2000 for a total of 9 surveys. The survey was not performed in 1999 for logistical reasons.

Additional control snorkeling surveys were conducted at 2 natural eelgrass meadows of similar depth during the same time period $(n=9)$. Eelgrass at the control sites was continuous (i.e. non-patchy) over the range of the survey area, but only plot areas similar to those at experimental sites were surveyed. This was accomplished by deploying $15 \mathrm{~m}$ transect lines perpendicular to shore at each control site. The vertical dimension and spacing of patches was marked on each transect line with pink surveyor's tape, while the horizontal dimension of patches was estimated by snorkelers swimming with delineated plastic poles over the transect lines. Snorkelers swam in parallel once over both transect lines at each site, so that only areas falling within the delineated transect lines were surveyed $\left(80 \mathrm{~m}^{2}\right)$.

Because of the difficulty in estimating fish size under water, potential predators within patches were sizecorrected by integrating seine and snorkel census data using the following equation:

$$
P_{\text {tot }}=\sum P_{\mathrm{sn}} P_{\mathrm{se}}
$$

where $P_{\text {tot }}$ is the total potential predators in the patch, $P_{\mathrm{sn}}$ is the total predators identified from snorkel surveys and $P_{\mathrm{se}}$ is the percentage of predators caught in the seine greater than $2 \times$ the mean tethered prey size (mm SL). From previous cod studies (Bogstad et al. 1994, Grant \& Brown 1998b, Linehan et al. 2001) we know that predators greater than $2 \times$ the prey size have the potential of capturing and consuming juvenile cod.

Data analysis. Tethering data were analyzed using an analysis of variance assuming a binomial error structure on logistically transformed data (log link;

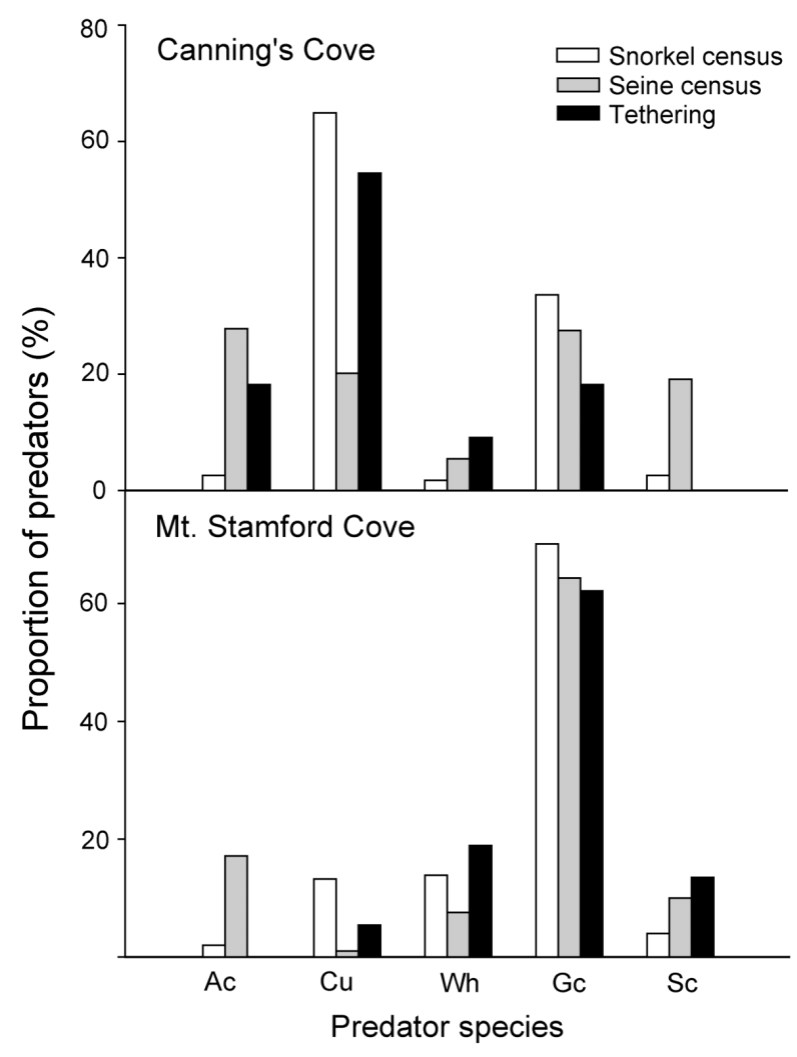

Fig. 4. Proportion of Age-0 cod predators determined by snorkeling, seining and tethering at Canning's Cove and Mt. Stamford in 2000. Proportions are based on 4 beach seine hauls, 288 tether sets and 9 snorkel surveys per site. Greenland cod Gadus ogac (Gc); Atlantic cod Gadus morhua (Ac); Cunners Tautogolabrus adspersus $(\mathrm{Cu})_{\text {; }}$ sculpin Myoxocephalus spp. (Sc); white hake Urophycis tenuis (Wh) 
proc GENMOD; SAS Release 6.03). 'Year', 'sampling period' and 'site' were used as explanatory variables. Significant interactions were found between year and site variables, so patches were analyzed separately in 1999 and 2000 within sites. The model assumed a uniform predator distribution; therefore, only patches with similar mean predator density (i.e. $\pm 2 \mathrm{SE}$ ) were analyzed. In this way, the effects of habitat structure on predation rates were measured independently of the predator distribution.

\section{RESULTS}

A total of 1152 tethering sets were conducted in both years at our 2 sites. Thirty-six sets were omitted from the analysis because lines were either tangled or fish were dead upon retrieval. The remaining 1116 tethering sets were considered successful, of which $12 \%$ (138 incidences) resulted in some form of predation. Predation events included 'caught predator' (48\%), 'hook gone' $(6 \%)$, 'fish gone' $(22 \%)$ and 'predator attack' $(24 \%)$. Predators retrieved on tether lines included Greenland cod $(18.7 \pm 3.9 \mathrm{~cm} \mathrm{SL})$, Atlantic $\operatorname{cod}(23.6 \pm 4.7 \mathrm{~cm} \mathrm{SL})$, cunner $(15.8 \pm 5.9 \mathrm{~cm} \mathrm{SL})$, sculpin $(17.0 \pm 5.8 \mathrm{~cm} \mathrm{SL})$ and hake $(12.6 \pm 0.5 \mathrm{~cm} \mathrm{SL})$. Higher overall predation was observed at MS (16\%) than CC $(9 \%)$.

Predator abundance increased with increasing patch size at both sites as expected (Fig. 3). However, the estimated composition of predators differed between sites as well as by census methods (Fig. 4). For example, cunners were found in greater abundance at CC, whereas hake were more numerous at MS. However, snorkel and seine surveys indicated that total predator abundance was higher at MS compared to CC. Census discrepancies included Atlantic cod and sculpins. Both were rarely seen over patches during snorkeling surveys but were often caught in seines and on tether lines. In contrast, cunners were often observed in artificial eelgrass patches yet comprised a smaller portion of total seine catch. However, seine, snorkel and tether data all indicated that Gadus ogac was an abundant predator at both sites (Fig. 4).

Distribution of predators among patches was similar between sites (Fig. 5). At MS, patch sizes of 0.3 to $11 \mathrm{~m}^{2}$ supported similar predator densities $(0.037 \pm$ 0.006 pred. $\mathrm{m}^{-2}$ ). In contrast, predator density in the largest patch $\left(22 \mathrm{~m}^{2}\right)$ was 2.3 times higher $(0.086 \pm$ 0.011 pred. $\mathrm{m}^{-2}$ ) than in the smaller patches. A similar distribution was observed in patches at $\mathrm{CC}_{i}$ predators densities in small patch sizes were nearly $50 \%(0.030 \pm$ 0.005 pred. $\left.\mathrm{m}^{-2}\right)$ of those in the largest patch size $(0.059$ \pm 0.08 pred $\mathrm{m}^{-2}$ ). Therefore, predator density was similar in all patches except the largest $\left(22 \mathrm{~m}^{2}\right)$ during snorkeling surveys. Differences in 1+ yr old Greenland cod abundance were responsible for this trend (Fig. 6). Although Greenland cod were evenly distributed within natural eelgrass meadows, they were disproportionately distributed among artificial eelgrass patches. Cunners and hake did not deviate consistently from expected trends at either eelgrass meadow or patch sites.

Predation rates increased with diminishing patch size at both sites during each year (Table 1, Fig. 7) when patches had similar predator density. Data collected from the largest patches $\left(22 \mathrm{~m}^{2}\right)$ were not included in the analysis because GENMOD assumes uniform predator distribution; only patch sizes 1 to 4 could meet these assumptions. In 2000, there was a significant effect of sampling date on predation rates at both sites; however, no interaction was detected between sampling date and patch (Table 1). Highest predation occurred outside the patches at rates similar to those found over the smallest patches (Fig. 7). Lowest predation was observed in the largest patches analyzed, i.e. $11 \mathrm{~m}^{2}$.

\section{DISCUSSION}

Structural complexity provides refuge to juvenile fish in freshwater (e.g. Crowder \& Cooper 1982, Savino \& Stein 1982, Werner et al. 1983a,b, Gotceitas \& Colgan 1989) and marine (e.g. Sale 1991) systems over a wide range of latitudes (Heck \& Wilson 1987). Numerous studies have shown that juvenile Atlantic cod use

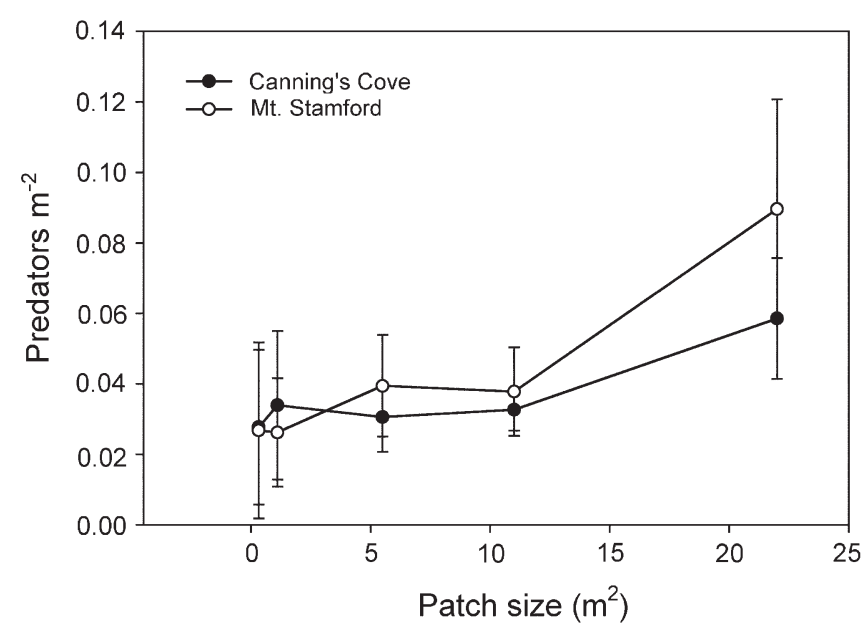

Fig. 5. Total density of piscivorous predators (Greenland cod Gadus ogac, Atlantic cod Gadus morhua, cunners Tautogolabrus adspersus, Myoxocephalus spp. and white hake Urophycis tenuis) in various sized patches of simulated eelgrass at Canning's Cove and Mt. Stamford. Values represent a mean of 9 snorkel surveys of 2 replicate patches $\pm 1 \mathrm{SE}$ 


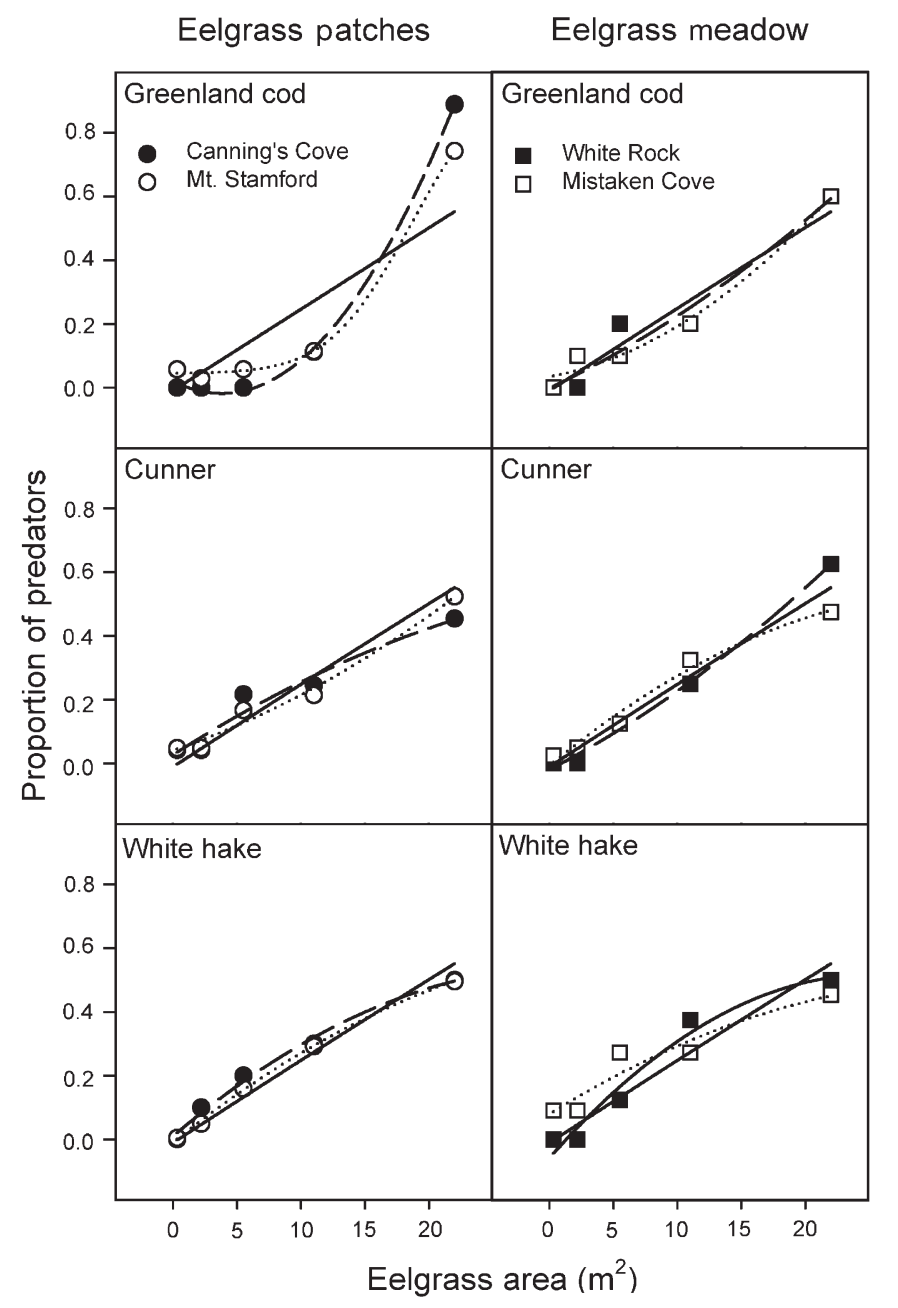

Fig. 6. Proportion of common piscivorous predators (Greenland cod Gadus ogac, cunners Tautogolabrus adspersus and white hake Urophycis tenuis) distributed over a range of artificial eelgrass patch sizes and equivalent areas at natural eelgrass meadows. Expected lines are calculated assuming a linear distribution of fish with area. Actual distributions are plotted with a best-fit quadratic equation to illustrate trends deviating from the expected linear distribution

complex habitats to reduce predation (e.g. Gotceitas \& Brown 1993, Gotceitas et al. 1995, 1997, Gregory \& Anderson 1997, Lindholm et al. 1999, 2001). Structurally complex habitats impair the visual and swimming capabilities of predators (Savino \& Stein 1982), which in turn can reduce the effectiveness of encountering, attacking and capturing prey (Tallmark \& Evans 1986). Our results were consistent with these findings. Predation rates of juvenile cod were highest over areas without structural complexity, i.e. unvegetated sand. However, we also show that the areal extent of surrounding refuge habitat, along with predator density, also influence the predation risk of small fish.
Age-0 juvenile cod were subjected to highest predation risk in smallest patches when predator density was uniform across all patch sizes. Fragmented habitat patches are considered risky because: (1) they have high perimeter to area ratios; and (2) the interior habitat is close to the edge and therefore, accessible to hunting piscivores. While these mechanisms have been explored in terrestrial systems (Brittingham \& Temple 1983, Andren et al. 1985, Andren 1992, Donovan et al. 1997), marine examples have been restricted to a number of invertebrate species (Irlandi 1997, Bologna \& Heck 1999, Peterson et al. 2001). Our results show that predation risk increases for fish in fragmented environments. Our analysis controlled for differential predator density and we suggest that the patch characteristics are directly responsible for the trend observed. We believe that risk was higher in small patches because of the associated changes in a predator's foraging ability, and not simply predator abundance.

Predator density was not uniform among all habitat patches. The largest seagrass patches $\left(22 \mathrm{~m}^{2}\right)$ attracted higher densities of piscivorous fish. Consequently, predation risk was higher in these patches than could have been predicted from habitat characteristics alone, i.e. patch size. Predator density and predation rates are positively correlated in studies of juvenile cod (Linehan et al. 2001, Gregory et al. unpubl. data). However, the non-linear distribution of predators with habitat area we observed in our study was unexpected. The

Table 1. GENMOD analysis of predation rates of tethered Gadus spp. on varying sampling dates, and artificial eelgrass patches as a function of year (1999 or 2000) and sampling location: Mt. Stamford (MS); Canning's Cove (CC)

\begin{tabular}{|clrrrr|}
\hline $\begin{array}{c}\text { Site } \\
\text { Year }\end{array}$ & $\begin{array}{l}\text { Source of } \\
\text { variation }\end{array}$ & df & Deviance & $\chi^{2}$ & $\mathrm{p}$ \\
\hline MS & & & & & \\
1999 & Date & 2 & 35.82 & 1.24 & 0.5379 \\
& Patch & 1 & 8.06 & 27.76 & $<0.0001$ \\
& Patch $\times$ Date & 2 & 7.34 & 0.72 & 0.6990 \\
& Intercept & 207 & 37.06 & & \\
2000 & Date & 2 & 30.63 & 11.98 & 0.0025 \\
& Patch & 1 & 21.04 & 9.59 & 0.0020 \\
& Patch $\times$ Date & 2 & 16.20 & 4.84 & 0.0890 \\
& Intercept & 276 & 42.61 & & \\
CC & & & & & \\
1999 & Date & 2 & 30.90 & 5.95 & 0.0510 \\
& Patch & 1 & 24.08 & 14.82 & 0.0090 \\
& Patch $\times$ Date & 2 & 9.70 & 4.38 & 0.0810 \\
& Intercept & 238 & 36.85 & & \\
2000 & Date & 2 & 42.95 & 15.27 & 0.0005 \\
& Patch & 1 & 15.51 & 27.44 & $<0.0001$ \\
& Patch $\times$ Date & 2 & 14.37 & 1.13 & 0.5681 \\
& Intercept & 278 & 58.22 & & \\
\hline
\end{tabular}




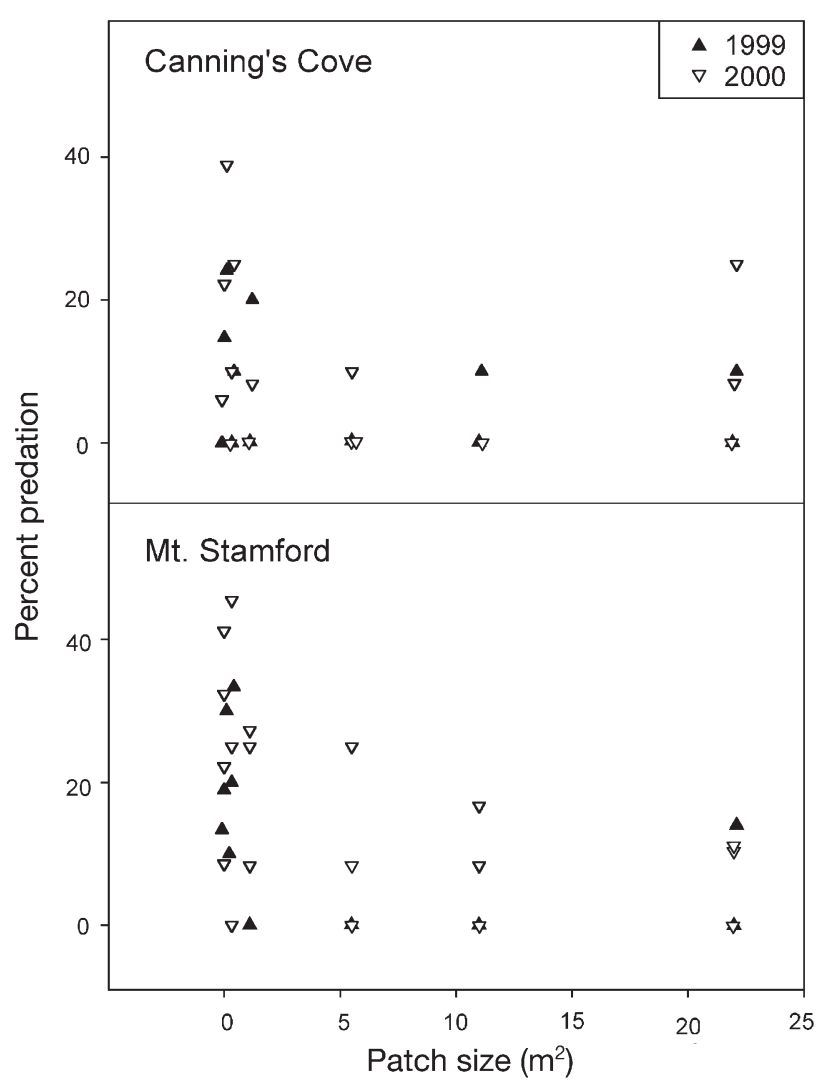

Fig. 7. Percent predation of juvenile cod Gadus spp. tethered in unvegetated areas $\left(0 \mathrm{~m}^{2}\right)$ and artificial eelgrass patches $\left(0.32,1.1,5.5,11\right.$ and $\left.22 \mathrm{~m}^{2}\right)$ at Canning's Cove and Mt. Stamford between 1999 and 2000. Values consist of 12 to 36 tether sets and are staggered $\pm 0.1 \mathrm{~m}$ to avoid overlap

higher predator densities in the large patches were due to increased abundance of Age-1+ Greenland cod, a species common in nearshore areas around Newfoundland (Methven et al. 2001) and a known predator of Age-0 cod (Linehan et al. 2001). The distribution of Greenland cod at the control sites (eelgrass meadows) was linear, indicating that this result was not due to overall patch layout, small changes in depth, distance from shore or area surveyed. Rather, it appears that changes in Greenland cod density were a function of eelgrass patch size.

Nonlinear associations between habitat and organisms are not unique to our study; however, the causal mechanisms are uncertain. Species-area curves typically increase with patch size (MacArthur \& Wilson 1967) and for some species, density has been related to habitat area. For example, European jays Garrulus glandarius L. and ravens Corvus corax L. are commonly found in large wooded areas, yet are entirely absent from smaller forest fragments (Andren 1992). Similar findings have been reported for other bird species (Stoufer \& Bierregaard 1995) and many species of invertebrates (Kareiva 1985, Margules et al. 1994, Ingham \& Samways 1996, Golden \& Crist 1999), including infaunal macroinvertebrate assemblages in eelgrass (Bowden et al. 2001). Small, fragmented patches may not have suitable food or niche space (Galli et al. 1976, Martin 1981) or refuge characteristics (Martin 1988) that large patches offer. Eelgrass is known to both concentrate prey (Connolly 1997) and provide shelter to piscivorous fish from predators (Orth et al. 1984). Therefore, predatory Greenland cod may use large patches of eelgrass to balance feeding success with their risk of being eaten. Our results suggest that predation risk changes with patch size for small cod $(<10 \mathrm{~cm})$; however, whether such an explanation applies to the distribution of larger fish (e.g. Greenland cod) is unknown.

We detected no interaction between date and patch size, suggesting that trends in predator distribution and risk were maintained within the temporal scale of our study. However, diel, monthly, seasonal and annual changes in piscivorous predators are variable in nearshore areas around Newfoundland (Clark \& Green 1990, Linehan et al. 2001, Methven et al. 2001). Therefore, observed trends of predator distribution in our study may not uphold at finer (e.g. diel) or broader (e.g. seasonal) temporal scales. Furthermore, such trends will not necessarily result in predictable changes in predation risk for juvenile cod. For example, Linehan et al. (2001) demonstrated a decrease in predation risk at night on Age-0 juvenile cod, despite increased density of larger conspecifics. Similarly, seasonal differences in temperature can affect the metabolic demands of piscivorous fish and consequently, risk to their prey species. Overwintering predation in many aquatic systems is therefore considered negligible (e.g. Keast 1978). We restricted our study to the timescale August to October, a time of year when juvenile cod predation risk is high (Linehan et al. 2001, Gregory et al. unpubl. data) and effects of predator distribution on the risk of juvenile cod to predation would be highest.

Inconsistencies in predator density estimates between our seine, snorkeling and tethering techniques are likely methodological artifacts. We suspect that seining more accurately samples predators than visual census. Previous work has demonstrated that demersal fish are caught by our seine technique with $95 \%$ efficiency (Gotceitas et al. 1997), whereas visual methods can underestimate density due to diver avoidance and fish crypsis (Keats 1990). We estimated density within individual eelgrass patches visually because the seine was not suited to sampling at small spatial scales (ca. 1 to $25 \mathrm{~m}^{2}$ ). The visual census more closely matched seine estimates for site-attached piscivores (e.g. Greenland cod, hake, cunners) that 
remained associated with eelgrass patches when approached. However, some fish did not associate with patches at these small scales. For example, we routinely observed Age-1+ Atlantic cod within close proximity to patches, but we did not include these fish in our abundance estimates as they were 'outside' the patch area. Consequently, Atlantic cod were underestimated in snorkel surveys relative to seine catches. Some piscivores may have also been underestimated by our tethering technique due to differential foraging capabilities. For example, cunners were rarely caught on tether lines at our sites, yet they were relatively abundant in the areas. Cunners are considered to be omnivorous, feeding preferentially on mollusks and amphipods rather than fish (Scott \& Scott 1988). Prey selection is known to be gape-limited (e.g. Schmitt \& Holbrook 1984) and cunners, with their small mouths, may have been restricted in their ability to handle our tethered prey in an equal manner to other similarsized predators, e.g. Greenland cod or sculpins. However, we have observed in situ foraging attempts of large cunners (ca. $25+\mathrm{cm}$ ) on Age-0 cod in Newman Sound.

There are limitations of the tethering technique as a means of measuring predation risk in the field. Tethering studies are numerous, including a wide variety of marine and freshwater organism such as decapod crustacea (Heck \& Wilson 1987, Eggleston et al. 1990, Wilson et al. 1990), bivalves (e.g. Arsenault \& Himmelman 1996), freshwater fish (Gregory \& Levings 1998, Post et al. 1998) and marine fish (Curran \& Able 1998, Linehan et al. 2001). The technique has its detractors (e.g. Halpin 2000, Kneib \& Scheele 2000, Peterson \& Black 1994) who have suggested that artifacts confound estimates of predation risk. As a technique to measure relative predation risk between similar habitats, such artifacts are unlikely to confound our interpretations (see Linehan et al. 2001).

In summary, our study is the first to measure the effects of habitat patch size on predation rates in a marine fish species. Eelgrass afforded greater protection to juvenile cod than unvegetated habitat, but both habitat patch size and predator distribution also contributed to differential rates of predation. Small eelgrass patches were riskier to juvenile cod than large patches when predators were evenly distributed; however, risk often increased in large patches due to higher predator densities. These results stress the importance of considering both habitat patch dimension as well as predator distribution and abundance when evaluating habitat quality for small fish.

Acknowledgements. This project was supported by Natural Sciences and Engineering Research Council of Canada (NSERC) Strategic Projects Grant \#20234. We would also like to thank Parks Canada (Terra Nova National Park) for providing accommodation and access to facilities, and the Department of Fisheries and Oceans for boats and motors. Finally, we are indebted to J. Anderson, L. Copeman, D. Cote, P. Frampton, D. Gibson, A. M. Gorman, J. Hancock, L. Hancock, D. Ings, M. O. T. Lander, A. Ogilvie, P. Sargent, K. Smedbol and N. Wells for the countless hours spent constructing artificial eelgrass and for their efforts in the field.

\section{LITERATURE CITED}

Andren H (1992) Corvid density and nest predation in relation to forest fragmentation: a landscape perspective. Ecology 70:794-804

Andren H, Angelstam P, Linstrom E, Widen P (1985) Differences in predation pressure in relation to habitat fragmentation: an experiment. Oikos 45:273-277

Arsenault DJ, Himmelman JH (1996) Size-related changes in vulnerability to predators and spatial refuge use by juvenile Iceland scallops Chlamys islandica. Mar Ecol Prog Ser 140:115-122

Bogstad B, Lilly GR, Mehl S, Palsson OK, Stefansson G (1994) Cannibalism and year-class strength in Atlantic cod (Gadus morhua L.) in Arcto-boreal ecosystems (Barents Sea, Iceland, and eastern Newfoundland). ICES Mar Sci Symp 198:576-599

Bologna PAX, Heck KL Jr (1999) Differential predation and growth rates of bay scallops within a seagrass habitat. J Exp Mar Biol Ecol 239:299-314

Bowden DA, Rowden AA, Attrill MJ (2001) Effect of patch size and in-patch location on the infaunal macroinvertebrate assemblages of Zostera marina seagrass beds. J Exp Mar Biol Ecol 259:133-154

Brittingham MC, Temple SA (1983) Have cowbirds caused forest songbirds to decline? BioScience 33:31-35

Clark DS, Green JM (1990) Activity and movement patterns of juvenile Atlantic cod, Gadus morhua, in Conception Bay, Newfoundland, as determined by sonic telemetry. Can J Zool 68:1434-1442

Connolly RM (1997) Differences in composition of small, motile invertebrate assemblages from seagrass and unvegetated habitats in a southern Australian estuary. Hydrobiologia 346:137-148

Crowder LB, Cooper WE (1982) Habitat structural complexity and the interaction between bluegills and their prey. Ecology 63:1802-1813

Curran MC, Able KW (1998) The value of tethering fishes (winter flounder and tautog) as a tool for assessing predation rates. Mar Ecol Prog Ser 163:45-51

Donovan TM, Jones PW, Annand EM, Thompson FR III (1997) Variation in local-scale edge effects: mechanisms and landscape context. Ecology 78:2064-2075

Eggleston DB, Lipcius RN, Miller DL, Coba-Cetina L (1990) Shelter scaling regulates survival of juvenile Caribbean spiny lobster Panulirus argus. Mar Ecol Prog Ser 62:79-88

Fonseca MS (1992) Restoring seagrass systems in the United States. In: Thayer GW (ed) Restoring the nation's marine environment. Maryland Sea Grant Publication, College Park, MD, p 79-110

Galli AE, Leck CF, Forman RT (1976) Avian distribution patterns in forest islands of different sizes in central New Jersey. Auk 93:356-365

Golden DM, Crist TO (1999) Experimental effects of habitat fragmentation on old-field canopy insects: community, guild and species responses. Oecologia 118:371-380

Gotceitas V, Brown JA (1993) Substrate selection by juvenile 
Atlantic cod (Gadus morhua): effects of predation risk. Oecologia 93:31-37

Gotceitas V, Colgan P (1989) Predator foraging success and habitat complexity: quantitative test of the threshold hypothesis. Oecologia 80:158-166

Gotceitas V, Fraser S, Brown JA (1995) Habitat use by juvenile Atlantic cod (Gadus morhua) in the presence of an actively foraging and non-foraging predator. Mar Biol 123: 421-430

Gotceitas V, Fraser S, Brown JA (1997) Use of eelgrass beds (Zostera marina) by juvenile Atlantic cod (Gadus morhua). Can J Fish Aquat Sci 54:1306-1319

Graham S, Davis J, Deegan L (1998) Effect of eelgrass (Zostera marina) density on the feeding efficiency of mummichog (Fundulus heteroclitus). Biol Bull 195:241-243

Grant SM, Brown JA (1998a) Nearshore settlement and localized populations of age 0 Atlantic cod (Gadus morhua) in shallow coastal waters of Newfoundland. Can J Fish Aquat Sci 55:1317-1327

Grant SM, Brown JA (1998b) Diel foraging cycles and interactions among juvenile Atlantic cod (Gadus morhua) at a nearshore site in Newfoundland. Can J Fish Aquat Sci 55: $1307-1316$

Gregory RS, Anderson JT (1997) Substrate selection and use of protective cover by juvenile Atlantic cod (Gadus morhua) in inshore waters of Newfoundland. Mar Ecol Prog Ser 146:9-20

Gregory RS, Levings CD (1998) Turbidity reduces predation on migrating juvenile Pacific salmon. Trans Am Fish Soc 127:275-285

Halpin PM (2000) Habitat use by an intertidal salt-marsh fish: trade-offs between predation and growth. Mar Ecol Prog Ser 198:203-214

Heck KL Jr, Wilson KA (1987) Predation rates on decapod crustaceans in latitudinally separated seagrass communities: a study of spatial and temporal variation using tethering techniques. J Exp Mar Biol Ecol 107:87-100

Ingham DS, Samways MJ (1996) Application of fragmentation and varigation models to epigaeic invertebrates in South Africa. Conserv Biol 10:1353-1358

Irlandi EA (1997) Seagrass patch size and survivorship of an infaunal bivalve. Oikos 78:511-518

Kareiva P (1985) Finding and losing host plants by phyllotreta: patch size and surrounding habitat. Ecology 66:1809-1816

Keast A (1978) Trophic and spatial interrelationships in the fish species in an Ontario temperate lake. Environ Biol Fish 3:7-31

Keats D (1990) A nocturnal inshore movement of juvenile cod Gadus morhua L. in eastern Newfoundland. J Exp Mar Biol Ecol 139:167-173

Kneib RT, Scheele CEH (2000) Does tethering of mobile prey measure relative predation potential? An empirical test using mummichogs and grass shrimp. Mar Ecol Prog Ser 198:181-190

Levenson JB (1981) Woodlots as biogeographic islands in southeastern Wisconsin. In: Burgess RL, Sharpe DM (eds) Forest island dynamics in man-dominated landscapes. Springer-Verlag, New York, p 13-39

Lindholm JB, Auster PJ, Kaufman LS (1999) Habitat-mediated survivorship of juvenile (0-year) Atlantic cod Gadus morhua. Mar Ecol Prog Ser 180:247-255

Linehan JE, Gregory RS, Schneider DC (2001) Predation risk of age 0 cod (Gadus morhua) relative to depth and substrate in coastal waters. J Exp Mar Biol Ecol 263:25-44

MacArthur RH, Wilson EO (1967) The theory of island biogeography. Monographs in population biology, Vol 1. Princeton University Press, Princeton, NJ
Margules CR, Milkovits GA, Smith GT (1994) Contrasting effects of habitat fragmentation on the scorpion Cercophonius squama and an amphipod. Ecology 75:2033-2042

Martin TE (1981) Species-area slopes and coefficients: a caution on their interpretation. Am Nat 118:823-837

Martin TE (1988) Habitat and area effects on forest bird assemblages: is nest predation an influence? Ecology 69: $74-84$

Methven DA, Bajdik C (1994) Temporal variation in size and abundance of juvenile Atlantic cod (Gadus morhua) at an inshore site off eastern Newfoundland. Can J Fish Aquat Sci 51:78-90

Methven DA, Schneider DC (1998) Gear-independent patterns of variation in catch of juvenile Atlantic cod (Gadus morhua) in coastal habitats. Can J Fish Aquat Sci 55: $1430-1442$

Methven DA, Haedrich RL, Rose GA (2001) The fish assemblage of a Newfoundland estuary: diel, monthly and annual variation. Estuar Coast Shelf Sci 52:669-687

Mittelbach GG (1986) Predator-mediated habitat use: some consequences for species interactions. Environ Biol Fish 16:159-169

Orth RJ, Heck KL Jr, van Montfrans J (1984) Faunal communities in seagrass beds: a review of the influence of plant structure and prey characteristics on predator-prey relationships. Estuaries 7:339-350

Paton PWC (1994) The effect of edge on avian nest success: how strong is the evidence? Conserv Biol 8:17-26

Peterson CH, Black R (1994) An experimentalist's challenge: when artifacts of intervention interact with treatments. Mar Ecol Prog Ser 111:289-297

Peterson BJ, Thompson KR, Cowan JH Jr, Heck KL Jr (2001) Comparison of predation pressure in temperate and subtropical seagrass habitats based on chronographic tethering. Mar Ecol Prog Ser 224:77-85

Post JR, Parkinson EA, Johnston NT (1998) Spatial and temporal variation in risk to piscivory of age-0 rainbow trout: patterns and population level consequences. Trans Am Fish Soc 127:932-942

Robbins BD, Bell SS (1994) Seagrass landscapes: a terrestrial approach to the marine subtidal environment. Trends Ecol Evol 9:301-304

Sale PF (ed) (1991) The ecology of fishes on coral reefs. Academic Press, New York

Savino JF, Stein RA (1982) Predator-prey interactions between largemouth bass and bluegills as influenced by simulated vegetation. Trans Am Fish Soc 111:255-266

Savino JF, Stein RA (1989) Behavioural interactions between fish predators and their prey: effects of plant density. Anim Behav 37:311-321

Schmitt RJ, Holbrook SJ (1984) Gape-limitation, foraging tactics and prey size selectivity of 2 microcarnivorous species of fish. Oecologia 63:6-12

Scott WB, Scott MG (1988) Atlantic fishes of Canada. Can Bull Fish Aquat Sci 219, University of Toronto Press, Toronto

Sogard SM (1997) Size-selective mortality in the juvenile stage of teleost fishes: a review. Bull Mar Sci 60: $1129-1157$

Sogard SM, Able KW (1991) A comparison of eelgrass, sea lettuce macroalgae, and marsh creeks as habitats for epibenthic fishes and decapods. Estuar Coast Shelf Sci 33:501-519

Stouffer PC, Bierregaard RO Jr (1995) Use of Amazonian forest fragments by understory insectivorous birds. Ecology 76:2429-2445

Taggart CT, Anderson J, Bishop C, Colbourne E and 6 others (1994) Overview of cod stocks, biology, and environment 
in the Northwest Atlantic region of Newfoundland, with emphasis on northern cod. ICES Mar Sci Symp 198: 140-157

Tallmark B, Evans S (1986) Substrate-related differences in antipredator behaviour of two gobiid fish species and the brown shrimp, and their adaptive value. Mar Ecol Prog Ser 29:217-222

Tupper M, Boutilier RG (1995) Effects of habitat on settlement, growth, and post-settlement survival of Atlantic cod (Gadus morhua). Can J Fish Aquat Sci 52:1834-1841

Editorial responsibility: Otto Kinne (Editor), Oldendorf/Luhe, Germany
Werner EE, Gilliam JF, Hall DJ, Mittlebach GG (1983a) An experimental test of the effects of predation risk on habitat use in fish. Ecology 64:1540-1548

Werner EE, Mittlebach GG, Hall DJ, Gilliam JF (1983b) Experimental tests of optimal habitat use in fish: the role of relative habitat profitability. Ecology 64:1525-1539

Wilson KA, Able KW, Heck KL Jr (1990) Predation rates on juvenile blue crabs in estuarine nursery habitats: evidence for the importance of macroalgae (Ulva lactuca). Mar Ecol Prog Ser 58:243-251

Submitted: June 27, 2002; Accepted: January 15, 2003

Proofs received from author(s): March 25, 2003 